\title{
Political Language, Causal Stories, and Pesticide Regulation
}

\author{
Dwight C. Kiel, University of Central Florida \\ Anthony J. Nownes, University of Tennessee
}

This article begins with the premise that the subgovernments which had dominated policymaking since the 1940s have given way to more amorphous and nebulous networks of influence. Given this fact, we ask: how have entrenched interests-those who had previousiy dominated subgovernment politics-reacted to the dissolution of their subgovernments? Focusing on one entrenched interest-pesticide manufacturers and their representatives-we argue that one response strategy is "going public" by (1) offering new causal stories which contradict the claims of new policy "players," (2) using political language designed to capture the "linguistic high ground," and (3) "framing" issues to favorably change the outlines of the debate. Ultimately, we argue that the dissolution of subgovernments has led to the "politicization" of many issues, which in turn has led to the increased use of language, causal stories, and symbols, as tools in policy battles.

As Jeffrey Berry has noted, "few approaches for studying the American political system have endured as long or as well as that of the policy subgovernment" $(1989,239)$. There is evidence, however, that this approach is archaic. Hugh Heclo (1978), for example, argues that the language of subgovernment theory is inadequate to explain the complexity of contemporary policy-making. In many issue areas subgovernments have been replaced by more open and permeable "issue networks."

Yet, despite an impressive literature on the decline of subgovernments (Heinz et al. 1993; Miller 1985; Peterson and Walker 1986; Walker 1983), political scientists largely have ignored one important question: how have entrenched interests - those which in the past had dominated subgovernment policy-making-reacted to challenges to their once-dominant policy roles? This is the question we seek to explore in the context of one policy area.

\section{Framing the Question}

A "policy subgovernment" can be defined as "a tight alliance of interest groups, program administrators, and legislative committees that formulates policy primarily for the benefit of a particular constituency" (Browne 1986, 183). As William P. Browne notes, subgovernment policy-making is marked

Dwight C. KIEL is Assistant Professor of Political Science at the University of Central Florida. Anthony J. Nownes is Assistant Professor of Political Science at the University of Tennessee.

The American Review of Polutics, Vol. 15, Winter, 1994: 491-506

Q 1994 The American Review of Politics 
by three basic characteristics. First, policy decisions are "the byproduct of bargaining among partners with narrow interests whose participation seldom involves them with anyone other than this small cluster of policy makers" (Browne 1986, 184). Second, the primary participants in a subgovernment are "legislative committee members, program administrators, and interest representatives" (Browne, 1986 184). And finally, subgovernments are marked by their "self-serving results"-they "specifically reward the primary constituencies of the triangle's participants, often to the detriment of the public at large" (Browne 1986, 185).

The subgovernment model proved useful because it provided a fairly accurate portrait of policy-making in a number of issue areas, as indicated by studies of the pesticide subgovernment (Bosso 1986), the "manpower" subgovernment (Davidson 1975), and the "smoking" subgovernment (Fritschler 1975). Yet the subgovernment perspective seemed ill-suited for the complex policy-making environment of the 1970s and 1980s. As James Q. Wilson (1980) noted in his study of regulatory policy, by the 1970s tight subgovernments were the exception rather than the rule. The "cozy triangles" Wilson did find were "made of metal far more malleable than iron" (391). And in his classic formulation, Hugh Heclo (1978) argued that subgovernments had given way to "issue networks" which "comprise a large number of participants with quite variable degrees of mutual commitment or of dependence on others in their environment" (102). Heclo also noted that "it is almost impossible to say where a network leaves off and its environment begins" (102).'

Issue network politics differ from subgovernment politics in two crucial respects. First, issue networks comprise a much larger number of participants. It is primarily this proliferation of interests that has led to changes in policy-making within issue areas once "ruled" by subgovernments. ${ }^{2}$ Second, issue networks are more permeable than subgovernments. In short, as Heinz et al. (1993) recently have argued, in most policy areas "major policy decisions are not made by closed circles of interest groups" and "numerous interest groups monitor any given policy question and consider taking a more active role in the debate" (380). By the late 1980s, interest group scholars more or less had accepted the notion that in many policy areas, subgovernments had given way to more open, conflictual, and permeable networks of influence. ${ }^{3}$

\section{What Happens When Subgovernments Fall Apart?}

The evolution of subgovernments toward more open policy-making networks has a number of important implications. Among them is that policy- 
making in an issue area in which a subgovernment has declined is likely to be marked by a great deal of complexity and to be "much more conflictual than ever before" as a wider variety of interests become involved (Walker 1991, 40; See also Gais, Peterson \& Walker 1984; Nordlinger 1981). Moreover, the decline of subgovernment politics has led to more visible politics. This is primarily due to the intrusion of formerly excluded players. As Heinz and his colleagues have noted $(1993,377)$, actors previously excluded from subgovernment politics-especially citizen and "externality" groupsare likely to introduce considerable instability into policy networks and to "disturb existing relationships between officials and interests." One of the important ways such groups introduce instability is by attempting "mass public mobilization" through the use of "dramatic, head-line grabbing strategies rather than the inside strategies of negotiation" (Heinz et al. 1993, 377).

What happens when subgovernments fall apart? It is not likely that formerly dominant players in subgovernment politics simply accept their diminishing influence. Rather, they are likely to engage in sophisticated counter-punching in hopes of neutralizing challenges to their policy dominance. But how? One way entrenched interests respond to challenges to their influence is by paying increased attention to public opinion. As Walker $(1991,192)$ argues: "groups that experience little conflict and enjoy close, cooperative relationships with government are unlikely to spend much time trying to influence public opinion." Ripley and Franklin (1987, chs. 1 \& 5) make a similar point. Conversely, groups that experience a high level of conflict must pay close attention to public opinion.

\section{One Response: Political Language, Causal Stories, and Symbolism}

It is our contention that one manifestation of this increased attention to public opinion by formerly entrenched interests is a heightened attention to political language, causal stories, and the use of symbols. We base our thesis largely on the fact that the dissolution (or, if you prefer, evolution) of a subgovernment is, at least partially, a result of the "politicization" of the issue involved. By "politicization" we mean that an issue, or set of issues, has become openly contested. Subgovernments are characterized by issues that are either "de-politicized" or "un-politicized," which is why policy-making in subgovernments is insulated and cooperative. The insulation of subgovernment actors provides few incentives to devote much attention to careful use of public language. However, the politicization-or opening of the policy area to broader public scrutiny-of issues within a policy area results in the participation of many previously excluded 
Table 1. Interests Represented at FIFRA 1947 House Committee Hearings

\section{INDUSTRY AND BUSINESS INTERESTS}

Agricultural Insecticide and Fungicide Association

Interstate Manufacturers Association

National Association of Insecticide and Disinfectant Manufacturers

B.T. Babbit Co.

Manufacturing Chemists Association

\section{AGRICULTURAL INTERESTS}

American Farm Bureau Federation

National Council of Farm Cooperatives

Agricultural Industrial Commission

\section{GOVERNMENTAL INTERESTS}

Fish and Wildlife Service

National Association of Commissioners, Secretaries, and Directors of Agriculture State Chemist, North Carolina

U.S. Department of Agriculture

Rep. Harris Ellsworth, Oregon

\section{CITIZEN AND LABOR INTERESTS}

None

*This organization later changed its name to the National Agricultural Chemicals Association.

Source: U.S. House. House Committee on Agriculture. Federal Insecticide, Fungicide, and Rodenticide Act. Hearings, 11 April 1947. Washington, D.C.: Government Printing Office. 1947. (Y4.Ag8/1:F31/7).

"players" (many of whom themselves seek to mobilize public opinion in one way or another) and thus demands that actors who wish to remain powerful pay close attention to the use of language, the construction of symbols, and the creation of causal stories about how the world works. Failure to do so can result in losing critical public debates about the course of future policymaking. None of this is to say that public opinion was not important in subgovernment politics. We do not argue that entrenched actors in subgovernments never offered causal stories, attempted to manipulate political symbols, or paid close attention to political language. Rather, we contend that the dissolution of subgovernments has led to a heightened (and very substantial) attention on the part of previously insulated subgovernment actors to political language, causal stories, and political symbols. These very 
public strategies of influence simply are seldom if ever necessary (or less frequently necessary) during subgovernment "politics as usual."

\section{The Decline of the Pesticide Subgovernment}

We believe that pesticide policy-making provides an ideal context in which to test our thesis. Prior to the 1980 s, pesticide policy was a paradigm of the iron triangle model (Bosso 1986). However, challenges to the pesticide subgovernment began to develop in the 1960 s, and by the 1980 s the subgovernment had ceased to exist. ${ }^{4}$ To demonstrate how much the subgovernment had changed by the 1980s, consider Tables 1 and 2. Table 1 contains a list of interests represented at the 1947 House Agriculture Committee hearings on the Federal Insecticide, Fungicide, and Rodenticide Act (FIFRA - the first major piece of legislation dealing with the regulation of pesticides). The table is self-explanatory and the contours of the subgovernment are clearly delineated. ${ }^{5}$ Table 2 contains a list of the interests represented at the 1987 House Agriculture Committee hearings on proposed amendments to FIFRA. Clearly, by 1987 the dominant position of chemical manufacturers and their supporters in government was challenged as never before.

To test our thesis we ask, how has one corner of the old pesticide "iron triangle"-that occupied by pesticide manufacturers and their representatives-responded to the decline of its subgovernment? We argue that pesticide manufacturers were not quiescent when their dominance was challenged in the 1980s. Instead, they waged a concerted campaign designed to fend off government regulation and negative public perceptions. A large part of this campaign (though certainly not the only part) involved offering new language, new symbols, and a reinvigorated causal story, to the public and to policy-makers. In short, as the politics of pesticide regulation changed, so did the political strategies of pesticide manufacturers. In a newly open policy-making environment manufacturers used language, symbolism, and a causal story to buttress their policy claims.

Given the pesticide example and the decline of subgovernment policymaking, we believe that policy scholars must pay more (and more careful) attention to language, symbols, and causal stories. The politicization of policy issues leads to power struggles that are public and that are located, at least in part, in the domain of language. Those actors whose power has been threatened and/or diminished in the dissolution of the old subgovernments must try to protect or reconstruct that power with language. 


\title{
Table 2. Interests Represented at FIFRA (Amendments) 1987 House Committee Hearings
}

\author{
INDUSTRY AND BUSINESS INTERESTS \\ American Wood Preservers Institute \\ American Sod Producers Association \\ Chemical Producers and Distributors Association \\ Chemical Specialties Manufacturing Association \\ ConAgra Inc. \\ Florida Fruit and Vegetable Association \\ FMC Corp. \\ Golf Course Superintendents Association \\ Griffin Corp. \\ Grocery Manufacturers of America Inc. \\ National Agricultural Aviation Association \\ National Agricultural Chemicals Association \\ National Arborist Association \\ National Food Processors Association \\ National Forest Products Association \\ National Pest Control Association \\ Prentiss Drug and Chemical Corp. \\ Professional Lawn Care Association of America \\ United Fresh Fruit and Vegetable Association
}

\section{AGRICULTURAL INTERESTS}

American Farm Bureau Federation

American Association of Nurserymen

Cotton and Grain Producers of the Lower Rio Grande Valley

National Cattleman's Association

National Council of Agricultural Employees

Ohio Pesticide Applicators for Responsible Regulation

\section{GOVERNMENTAL INTERESTS}

Department of Environmental Conservation, State of New York

Environmental Protection Agency

Montgomery (Md.) County Council

Prince Georges County Government

State of California

State of Iowa

State of Maryland

State of Montana

U.S. Department of Agriculture

CITIZEN AND LABOR INTERESTS

AFL-CIO

Center for Science in the Public Interest

Chesapeake Bay Foundation 
Table 2 (continued)

CITIZEN AND LABOR INTERESTS (cont.)

Consumers Union

Friends of the Earth

Human Ecology Action League

Humane Society of the United States

Maryland Alliance for Responsible Regulation of Pesticides

National Wildlife Federation

National Audobon Society

National Coalition Against the Misuse of Pesticides

Pesticide Public Policy Foundation

Public Citizen's Congress Watch

Public Voice for Food and Health Policy

Ralph Nader

Sierra Club

U.S. Public Interest Research Group

Source: U.S. House. House Committee on Agriculture. Federal Insecticide, Fungicide, and Rodenticide Act Amendments of 1987. Hearings, 7 April and 10, 16, 17 June 1987. Washington, DC: Government Printing Office. 1987. (Y4.Ag8/1: 100-13).

\section{Language, Causal Stories, and Public Policy}

When issues become publicly contested the use of language and the construction of causal stories become critical. We believe that in policy disputes and debates there are three distinct discourse strategies that become important for the participants. ${ }^{6}$

The first strategy one may deploy involves framing the issue in language that allows partisans in the conflict to capture the "linguistic high ground." This can be achieved by wrapping one's position in the flag or other deeply held social values, by moving from a negative articulation of one's position to a positive formulation, and/or by casting aspersions upon one's opponents. Two examples are illustrative of these approaches.

The battle for the linguistic high ground in the abortion debate illustrates the value of framing one's position in a positive manner. Opponents of abortion scored a public relations victory when they quit calling themselves "anti-abortion" forces and redubbed themselves "right to life" advocates. They were able to show their positive agenda as well as to reframe the pro-abortionists as a negative group that is "anti-life." Proponents of abortion responded to this, however, with their own attempt to recapture the linguistic high ground-they renamed themselves "pro-choice" advocates. 
And following through on the logic of their new liberty-grounded image, abortion proponents are now referring to their adversaries as "anti-choice" advocates.

The best recent example of a framing contest for the linguistic high ground was the effort by many members of Congress to relabel President Reagan's Strategic Defense Initiative (SDI) as "Star Wars." The purpose, of course, was to make SDI seem "Hollywood," remotely futuristic, and comical. The Reagan Administration, given its constant attempts to stick with SDI terminology, certainly understood the power that the "Star Wars" moniker had in undercutting the program. Regardless of the final outcome of the SDI program there can be little doubt that the opponents of SDI captured the linguistic high ground and forced the Reagan Administration into an uphill policy battle.

During and after the framing process, a second language strategy is deployed. Here, the emphasis is on renaming activities and objects so that they fit the new linguistic paradigm. In contested arenas one not only must seek the linguistic high ground, one also must rename (and recreate) the contested environment. For example, when the psychiatric profession found itself under attack in the early 1970s, it attempted to cleanse itself of its coercive and manipulative image by reframing itself as one of the "helping" professions. Within this new "helping" profession of psychiatry, both activities and objects were renamed. Escaping from a mental institution became "eloping," and the room designated for solitary confinement was renamed the "quiet room" (Edelman 1977, ch. 4).

We also can see this concern for naming in the abortion debate. For pro-choice advocates, pregnancies are "terminated" and an abortion involves the "removal of a fetus." For pro-life advocates, abortion is a process in which "an unborn child" is "killed."

A third strategy to deploy in contested issue areas is to develop a persuasive causal story that will promote certain types of action (or inaction). Different causal stories will lead, of course, to different interpretations of both the causes of, and the possible solutions to, social problems (Stone 1986). The importance of causal stories in agenda formation and in the contest between competing policy alternatives can be illustrated with a brief example.

Social and political responses to poverty in affluent industrial societies are shaped by predominant interpretations of the causes of poverty. Causal stories that rest on individual responsibility for poverty may keep poverty off the political agenda, or may lead-as it did in the Progressive Era-to a call for work in training camps (Haber 1973). Causal stories that emphasize the structural features of capitalism will tend to politicize poverty and 
lead to calls for public policy solutions or political revolution. In the United States, competition among rival causal stories about poverty remains keen, and no one version has been able to achieve hegemony.

Indeed, it may be difficult, even with the help of science, to make a causal story persuasive. The debate over public policy on cigarette smoking is a classic case in which questions of causality were central. Tobacco interests spared almost no expense to point out that statistical correlations do not prove causality. The Tobacco Institute-the public relations and lobbying arm of the tobacco industry-offered a variety of other causal stories to explain the correlations between smoking and lung cancer, including the claim that smokers were "risk-takers" in a wide variety of activities which might be linked to cancer (see Fritschler 1975). In the current policy debate over passive smoking the tobacco interests continue to contend that correlation is not causation.

In short, causal stories help shape public policy agendas and alternatives. However, the competition among causal stories is not easily resolved. In many policy areas there is no final recourse for deciding conclusively which of the competing causal stories is (the most) accurate. Scientific evidence can add strength to causal claims, but the statistical nature of science leaves it open to legitimate criticism regarding its claims concerning causal links. Advocates of competing claims thus must rely on persuasion and persistence.

\section{Language, Symbols, and Industry Response}

Prior to the mid-1980s, pesticide manufacturers-one leg of the old pesticide subgovernment-were not very concerned about language and symbols. Despite attempts by researchers such as Rachel Carson (1962) and Barry Commoner (1966) to politicize the issues surrounding pesticide use, there was little sustained public contest or controversy over pesticide use and regulation. ${ }^{7}$ Pesticide manufacturers, comfortable with the policy subsystem, had little reason to worry about public perceptions of their products.

However, by the mid-1980s, pesticide manufacturers had seen their subsystem collapse and had witnessed the politicization of pesticide use. ${ }^{8}$ As Bosso (1986) documents, (and as Tables 1 and 2 show), the pesticide subgovernment-dominant during the 1950s, 1960s, and early 1970s-lost shape in the 1980s. Pesticide manufacturers have responded to this collapse by engaging in all three of the highly public strategies discussed above. They set out to capture the linguistic high ground by reframing ideas about the purpose and role of pesticides. In addition, they used the "naming" strategy 
(by choosing new, less threatening names for their pesticides) to protect and enhance that high ground. And, finally, they developed a new causal story ${ }^{9}$ to protect themselves against government regulation and negative public perceptions.

It would be a mistake to conclude that prior to subgovernment dissolution pesticide manufacturers never had worried about public perceptions of their products. Clearly, however, by the 1980s the policy debate over pesticide regulation had changed. Specifically, "externality" groups had made public health concerns paramount on the policy agenda. ${ }^{10}$ Thus, the debate over pesticide regulation is now more public, more conflictual, and broader (in that it concerns the issue of consumer protection) than ever before. The "new politics" of pesticide regulation forced pesticide manufacturers to respond.

\section{Seeking the Linguistic High Ground: Framing and Renaming}

In the pesticide arena, the renaming process began before a clear articulation of the new linguistic high ground had emerged. We examined the naming process used by pesticide manufacturers by analyzing the product trade names used by some of the largest pesticide manufacturers in America. ${ }^{11}$ The U.S. Trademark Information File (May 1990) provides information on when companies file for new product trade names and on the trade names themselves. To determine if pesticide manufacturers had altered their naming strategies over the years we examined data on filing dates and trademark names. The data indicate that, prior to the $1960 \mathrm{~s}$, pesticide manufacturers named pesticides after their active chemical ingredient. However, during the 1960 s pesticide manufacturers increasingly began to rely on evocative names for their products. For example, Monsanto's "Lariat," "Rodeo," and "Ricochet" were three of the most popular pesticides of the 1960s. The data also show that in the late 1970s and early 1980s, companies began to use military names for their compounds. For example, American Cyanamid's "Arsenal," BASF's "Torpedo," Dow's "Bayonet," and Monsanto's "Militia" all were patented between 1977 and 1984.

In the late $1980 \mathrm{~s}$, pesticide manufacturers began to trademark new names that were less threatening. For example, in our coding of trade names we developed such categories as Harmony Names (e.g, Dow's "Accede," and Monsanto's "Accord"), Confidence Names (e.g., Chevron's "Superb," BASF's "Esteem" and "Confidence"), Celebration Names (e.g., Dow's "Pageant" and "Jamboree," Ciba-Geigy's "Award," and Monsanto's "Hark"), Patriotic Names (e.g., BASF's "Pledge," Dow's "Justice," and Monsanto's "Anthem" and "Freedom"), Judicial Names (e.g., Chevron's 
"Gavel," and Monsanto's "Jury" and "Judge"), and Green Names (e.g., Cenex's "Green Mountain," and Ciba-Geigy's "Greenpak"). We find it particularly significant that out of 99 pesticide compounds we analyzed that were patented between 1960 and 1990, 47 had names which fell into one of these six "harmony and confidence" categories; yet only one of these 47 was patented before 1985 .

To be sure, pesticide manufacturers continued to use military names throughout the 1980s. But between 1985 and 1990, only 18 of 68 compounds we found in the trademark file were given military names. This is in stark contrast to the number of pesticides given such names between 1980 and 1984. During this period, 13 of 21 pesticides found in the trademark file were given military names, while only one was given a harmony, confidence, celebration, patriotic, judicial, or green name.

In short, the data show that the naming of pesticides changed in the mid-1980s. Why? We believe the answer lies in the fact that it was during the 1980s that pesticide manufacturers for the first time grew concerned that pesticide issues were becoming publicly contested. Thus, a naming strategy was employed to evoke different responses to the same basic substances. An herbicide named "Green Mountain," for example, elicits a far different vision than one named "Torpedo."

There also is evidence that during the period of subgovernment collapse, pesticide manufacturers began attempting to frame pesticide use in a new way. In 1988, the National Agricultural Chemicals Association (NACA)-the trade association for pesticide manufacturers, which had been part of the pesticide subgovernment since the 1940s-founded a new, affiliated trade association which it named The Alliance for a Clean Rural Environment (ACRE). Note that the name itself is designed to evoke a friendlier, bucolic, and less threatening image. ACRE's stated goal is to provide pesticide users with "the useful, graphic information they need to protect water quality and become better stewards of the environment" (NACA 1990, 5). Since its founding, ACRE has sought to build a grassroots movement to buttress NACA's claims that agricultural chemicals are safe if properly used. By 1990, ACRE claimed more than 75,000 members who regularly receive "fact sheets" concerning everything from proper chemical use and storage, to tips for maintaining spray equipment. The material is presented in a manner designed to promote NACA's view that properly applied pesticides create no problems for the environment and that the pesticide companies are concerned environmental stewards.

ACRE works hard to reframe pesticide issues. The group has been especially concerned with the negative perception of pesticides in general, and the use of negative "cide" words-herbicide, pesticide, insecticide-in 
particular. Thus, in virtually all of ACRE's (and NACA's) communications, "cide" words have been replaced by the term "crop protection chemicals." "Crop protection chemicals" (CPCs) is a less threatening term than "pesticides, " and it brings out the positive attributes of such substances (i.e., they protect our food supply). This reframing of the issue allows the pesticide industry to begin debates with their opponents with the importance of protection already established, rather than having to begin the debate by defending themselves against the dangers (and collateral damage) of their products.

In another interesting language strategy, pesticide manufacturers have begun referring to the application of pesticides as pesticide "management." Applicators (managers?) are to be educated in the "best management practices." "Management" evokes a much more rational vision than application. Furthermore, management is seen as a science that can be taught effectively.

It is too early to tell if this renaming and reframing will be successful. The outcome of ongoing battles for linguistic high grounds is not easy to predict. However, we do wish to note that the term "CPCs" may itself be problematic, because of its similarity to the dreaded and deadly "PCBs"! Not even well-financed linguistic campaigns can anticipate the linkages that may be made when issues become publicly contested.

\section{A Causal Story}

Pesticide manufacturers have done more than simply seek to capture the linguistic high ground. They also have sought to affect the terms of debate by offering a causal story which casts them in a more favorable light. ACRE has been a key actor in shaping this new causal story. The pesticide industry and ACRE feel that there is a danger that the dominant causal story in pesticide policy is that pesticides cause collateral damage and death. Indeed, it can be argued that the success of externality groups in offering a causal story which paints pesticides in a negative light has triggered manufacturer's heightened attention to causal stories. ACRE, in its handsome and wellorganized literature, counters this causal story by claiming that the real problem with pesticides lies not with the product, but with the misapplication of the product. For ACRE, pesticides don't cause problems, misapplication by ignorant applicators causes problems. Given this interpretation, public policy should concentrate on making sure that all applicators are informed of the proper uses of particular pesticides, and that certification and registration of applicators is required if "restricted use" pesticides are used. 
This alternative causal story, of course, does have some merit. Misapplication of pesticides, whether through improper use or overapplication, does present dangers. ACRE has offered a causal story that places blame not on all applicators, nor even on malicious applicators, but on ignorant applicators that need well packaged information from ACRE. In short, ACRE and the pesticide manufacturers would like to avoid the debate on the dangers of pesticides, and relocate the debate in a more sanguine arena.

Some may argue that industry's position-that pesticides are inherently safe if used properly-has not changed since the 1940s. This is true. But it is significant that only during the 1980 s have pesticide manufacturers felt it necessary to sink substantial resources into publicly and consistently promoting this position. Because of subgovernment dissolution, pesticide manufacturers have had to devote more time and energy and resources into publicly defending their claims of inherent pesticide safety. Integral to this defense has been an attempt to capture the linguistic high ground and reframe the pesticide issue through the use of language.

\section{Lesson: A New and Very Public Response}

In sum, there is evidence that the collapse of the old pesticide subgovernment and the emergence of an issue network which engendered increased and public conflict over the regulation of pesticides has resulted in pesticide manufacturers responding with a coherent symbolic and linguistic package: crop protection chemicals with names like "Virtue" and "Freedom" can be used safely if applicators are informed and properly certified and licensed.

If the pesticide arena is not unique-and we believe that it is not-and if subgovernments in other arenas face similar collapse, then policy scholars must pay closer attention to the form, as well as the substance, of policy battles. Language, symbols, and causal stories, which were not always critical in the age of the iron triangle, must now be examined much more carefully.

\section{Conclusion}

We would like to point out that there may be other explanations for the changes we describe. For example, it may be the case that pesticide manufacturers have changed their behavior (e.g., renamed pesticide compounds and offered a new causal story) in response to changes in consumer behavior. We regret that we cannot provide definitive evidence to support our 
thesis. Nonetheless, we believe that there is substantial evidence to support our basic conclusion.

We have presented evidence that one way in which previously dominant interests respond to challenges to their influence is by engaging in the three language/symbol-based strategies discussed above. We present evidence that previously dominant pesticide industry interests did not respond to the collapse of the pesticide subgovernment quiescently. Instead, the industry created a new organization (ACRE) and began to articulate a coherent public message designed to fend off public interest groups and the threat of more extensive government regulation. The industry has begun a renaming process that protects the linguistic high ground being carved out by ACRE and that enhances the causal story ACRE promulgates about the limited dangers of pesticide use.

It is too early to assess the success of this public approach. The outcomes of public debates are difficult to predict, and language and symbols can be slippery. Nevertheless, given the politicization of pesticide policy, attention must be paid to language, symbols, and causal stories in this policy area. If the decline in other subgovernments also generates increased politicization of issues, then we expect that strategies and tactics similar to the ones deployed by the pesticide industry will be widespread. This paper represents a first cut at understanding contested public battles more clearly. New conditions engender new political strategies, both for participants in policy battles and for those observing, and trying to grasp, the action.

\section{NOTES}

${ }^{1}$ Issue networks are amorphous, but not completely without structure. For example, participants active in issue network politics are similar to those active in subgovernment politics. Interest groups, members of Congress, administrators-all are central players in issue network politics. Moreover, some participants in an issue network are more central than others (thus, they are involved in a wide range of issues) and many sub-groups of actors work together on a regular basis (see Heinz et al. 1993).

${ }^{2}$ For example, in his study of agriculture policy, William Browne (1986) notes that "expanding interests, groups, and types of organizations have created an implosion within whatever remains of the agricultural subsystem (197)."

${ }_{3}$ Some scholars, however, argue that the subgovernment model continues to hold some utility (see, for example, Milford and Wamsley 1984).

${ }^{4}$ Ripley and Franklin (1987) (among others) note that complete subgovemment collapse rarely occurs. However, their discussion of subgovernment adaptation and collapse takes place primarily within the context of distributive policy. Pesticide regulation seems to fit into their "protective regulatory policy" category. Their discussion of regulatory policy (unforunately) provides us few criteria by which to determine a functioning subgovernment from a disintegrated subgovernment. 
Thus we are comfortable, especially noting the excellent work of Bosso (1986), in stating that the pesticide subgovernment had indeed collapsed by the mid-1980s.

'The pesticide subgovernment consisted of the USDA (the bureaucratic agency responsible for implementing pesticide policy), chemical manufacturers (represented most prominently by the National Agricultural Chemicals Association) and their farm group allies (such as the Farm Bureau), and agriculture committee members in both houses of Congress.

${ }^{6} \mathrm{We}$ concluded that actors use these three strategies largely on the basis of the work of Murray Edelman. For example, see Edelman $(1971,1977)$. Edelman's emphasis is on how language and symbols are used to keep dis-empowered groups quiescent. In addition, sociological studies including Snow and Rochford (1986), Snow and Benford (1988), and Lynxwiler (1988) use a "framing" approach which we draw upon in our discussion of linguistic high ground and the importance of causal stories.

${ }^{7}$ As Bosso (1986) documents, however, there were occasional "flare-ups" of public attention.

${ }^{8}$ As Bosso (1986) documents, by the 1980 s, a number of players-including public interest groups, policy entrepreneurs in Congress, and bureaucrats from the Fish and Wildlife Service and the Dept. of the Interior-who had previously been excluded from the process had become quite active in pesticide policy.

"It could be argued that the causal story the pesticide manufacturers offered was not "new" at all-that pesticide manufacturers had always maintained that their products were safe if used properly. This is undoubtedly true. But our main point is that during the period of subgovernment dominance chemical manufacturers simply did not pay much attention to causal stories. Only after subgovernment collapse did pesticide manufacturers actively and very publicly deploy a causal story to defend/promote their interests.

${ }^{10}$ See Bosso (1986).

${ }^{11}$ The pesticide manufacturers we examined were: American Cyanamid, BASF, Cenex, Chevron, Ciba-Geigy, Dow, Monsanto, Shell, and Uniroyal.

\section{REFERENCES}

Berry, Jeffrey. 1989. Subgovernments, Issue Networks, and Political Conflict. In Mark P. Petracca, ed., The Politics of Interests. Boulder, CO: Westview Press.

Bosso, Christopher. 1986. Pesticides and Politics. Pittsburgh: University of Pittsburgh Press.

Browne. William P. 1986. Policy and Interests: Instability and Change in a Classic Issue Subsystem.

In Allan J. Cigler and Burdett A. Loomis, eds., Interest GroupPolitics, 2nd edition.

Washington, DC: Congressional Quarterly Press.

Carson, Rachel. 1962. Silent Spring. New York: Houghton Mifflin.

Commoner, Barry. 1966. Science and Survival. New York: Viking.

Edelman, Murray. 1971. Politics as Symbolic Action. Chicago: Markham. . 1977. The Symbolic Uses of Politics. Urbana, IL: University of Illinois

Press.

1977. Political Language: Words that Succeed and Policies That Fail. New York: Academic Press.

Fritschler, Lee. 1975. Smoking and Politics. New York: Appleton-Century-Crofts.

Davidson, Roger H. 1975. Policy Making in the Manpower Subgovernment. In M.P. Smith, ed., Politics in America. New York: Random House.

Gais. Thomas L., Mark A. Peterson. and Jack L. Walker. 1984. Interest Groups, Iron Triangles, and Representative Institutions in American National Government. British Journal of Political Science 14: 161-185.

Haber, Samuel. 1973. Efficiency and Uplift: Scientific Management in the Progressive Era, 18901920. Chicago: University of Chicago Press. 
Heclo, Hugh. 1978. Issue Networks and the Executive Establishment. In Anthony King, ed., The New American Political System. Washington DC: American Enterprise Institute.

Heinz, John P., Edward O. Laumann, Rober L. Nelson, and Rober H. Salisbury. 1993. The Hollow Core: Private Interests in National Policy Making. Cambridge, MA: Harvard University Press.

Lynxwiler, John. 1988. Framing the Picture that Rock Paints: A Frame Analysis of the Porn Rock Movement. Paper presented at the annual meeting of the American Sociological Society, Nashville, TN.

Milford, H. Brinton, and Gary L. Wamsley. 1984. Policy Subsystems, Networks, and the Tools of Public Management. In Robert Eyestone, ed., Public Policy Formation. Greenwich, CT: JAI Press.

Miller, Tim. 1985. Recent Trends in Federal Water Resource Management: Are the Iron Triangles in Retreat? Policy Studies Review 5: 345-412.

National Agricultural Chemicals Association (NACA). 1990. Annual Report. Washington, DC: NACA.

Nordlinger, Eric A. 1981. On the Autonomy of the Democratic State. Cambridge, MA: Harvard University Press.

Peterson, Mark A. and Jack L. Walker. 1986. Interest Groups and the Reagan White House. In Allan J. Cigler and Burdett A. Loomis, eds., Interest GroupPolitics, 2nd edition. Washington, DC: Congressional Quarterly Press.

Ripley, Randall B. and Grace A. Franklin. 1987. Congress, the Bureaucracy, and Public Policy, 4th ed. Homewood, IL: Dorsey Press.

Salisbury, Robert H., John P. Heinz, and Edward O. Laumann. 1986. Who Works with Whom?: Interest Group Alliances and Opposition. American Political Science Review 81: 1217-1234.

Snow, David A. and Robert D. Benford. 1988. Ideology, Frame Resonance, and Participant Mobilization. In Bert Klandermans, Hanspeter Kriesi, and Sidney Tarrow, eds., International Social Movements Research, Vol. I. Greenwich, CT: JAI Press.

Stone, Deborah. 1989. Causal Stories and the Formation of Policy Agendas. Political Science Quarterly 104: 281-300.

Walker, Jack L. 1991. Mobilizing Interest Groups in America: Patrons, Professions, and Social Movements. Ann Arbor, MI: University of Michigan Press.

. 1983. The Organization and Maintenance of Interest Groups in America.

American Political Science Review 77: 390-406.

Wilson, James Q. 1980. The Politics of Regulation. New York: Basic Books. 